Biol Neonat 1989;55:1-3

\title{
Contents, Vol. 55, No. 1, 1989
}

\section{Contents}

Foreword 5

Perinatal Health in Belgium: An Introduction

Buekens, P.; Derom, R.; De Wals, P 6

Perinatal Mortality and Morbidity

Perinatal Mortality in Belgium

De Wals, P.; Bertrand, F.; Verlinden, M.; Beckers, R

Perinatal Morbidity in Belgium

Lagasse, R.; Devlieger, H.; De Wals, P.; Casaer, P.; Eggermont, E.; Lechat, M.F 19

Maternal Mortality and Morbidity in Belgium

MacGillivray, I.; Spitz, B.; De Wei, M.; Van Assche, A 30

Perinatal Geography of Belgium

Vandenbussche, P.; Dujardin, B.; Wollast, E 34

Social Inequalities in Perinatal Health

Masuy-Stroobant, G 42

Perinatal Care

History of Prenatal Care in Belgium

Bande-Knops, J.; Renaer, M.; VanTongelen, E

Organization of Prenatal Care in Belgium

Humblet, P.C.; Wollast, E.; Vandenbussche, P.; Leleux, P.; Buekens, P 55

Organization of Obstetrical Care in Belgium

Derom, R.; Pelfrene, E.; Vlietinck, R.; Thiery, M

Organization of Neonatal Care in Belgium

Van Reempts, P.; Senterre, J 70

Author Index 76

Subject Index 76 